DOI: https://doi.org/10.11144/Javeriana.umed58-3.risk

\title{
Histological Findings in Very Low Risk Prostate Cancer Patients Managed with Radical Prostatectomy
}

\section{Hallazgos histopatológicos en pacientes con cáncer de próstata con criterios de muy bajo riesgo llevados a prostatectomía radical}

\begin{abstract}
Fundación Santa Fe de Bogotá University Hospital,
Colombia

Anamaría Ramos

Fundación Santa Fe de Bogotá University Hospital,

Colombia

Daniela Robledo

Fundación Santa Fe de Bogotá University Hospital,

Ángela Marcela Mariño Állvarez

Fundación Santa Fe de Bogotá University Hospital,

Colombia

Juan Guillermo Cataño

Fundación Santa Fe de Bogotá University Hospital,

Colombia

Juan Ignacio Caicedo

Fundación Santa Fe de Bogotá University Hospital,

Colombia

REBECA EsCOBAR

Fundación Santa Fe de Bogotá University Hospital,

Colombia

Mauricio Plata

Fundación Santa Fe de Bogotá University Hospital,
\end{abstract}

Carlos G. Trujillo ${ }^{a}$ Conflict of interest and financing:

Colombia

\begin{tabular}{lrr}
\hline a Correspondence & author. & E-mail: \\
cg.trujillo2592@uniandes.edu.co &
\end{tabular}

How to cite: Trujillo CG, Ramos A, Robledo D, Mariño Álvarez ÁM, Cataño JG, Caicedo JI, Escobar R, Plata M. Histological Findings in Very Low Risk Prostate Cancer Patients Managed with Radical Prostatectomy. Univ Med. 2017;58(3):xx-xx. doi: htt ps://doi.org/10.11144/Javeriana.umed58-2.risk

\begin{abstract}
Objectives: To describe the histological findings in patients with prostate cancer (PCa) clinically classified as very low risk who underwent treatment with radical prostatectomy (RP). Material and methods: A retrospective observational study was conducted. Clinical records of patients who underwent RP between 2007-2015 who met Epstein criteria for very low risk disease were reviewed. Histological diagnosis was described and analyzed to determine if such criteria predicted very low risk. Results: A total of 609 records were reviewed; 83 (13.6\%) met Epstein's criteria. Mean age was $59(\mathrm{SD} \pm 7)$ years and median PSA at diagnosis was $5.4 \mathrm{ng} / \mathrm{dl}$ (IQR 4.3 - 6.8). Pathology showed a median tumor volume of 4\% (IQR $1-10 \%)$. Gleason score was $3+3$ in $55(66.3 \%)$ cases, but $28(33.7 \%)$ were reclassified to a greater score. Two $(2.4 \%)$ patients were reclassified as pT3a, $80(96.4 \%)$ as pT2 and $1(1.2 \%)$ was found to be pTO. In those subjected to pelvic lymphadenectomy (42.2\%) no
\end{abstract}


positive lymph nodes were found. Conclusions: Up to onethird of the patients clinically classified with very low risk PCa had a greater Gleason score. Only 3\% had locally advanced tumors, which is comparable to previous studies. Epstein's criteria seem to be adequate in predicting organconfined disease.

Keywords

very low risk prostate cancer; radical prostatectomy; tumor stage.

\section{RESUMEN}

Objetivo: Describir los hallazgos de la patología definitiva de los pacientes inicialmente clasificados con tumores de muy bajo riesgo que fueron llevados a prostatectomía radical (PR). Materiales y métodos: Estudio observacional retrospectivo. Se revisaron las historias clínicas de pacientes llevados a PR entre enero de 2007 y diciembre de 2015. Se describieron y analizaron los hallazgos histopatológicos posquirúrgicos, con el objetivo de determinar si cumplir con dichos criterios eran predictores de enfermedad órgano-confinada y de bajo riesgo. Resultados: Se revisaron 609 historias clínicas de pacientes llevados a PR, de las cuales 83 (13,6\%) casos cumplían con criterios de muy bajo riesgo. La media de edad de estos pacientes fue de 59 (DE \pm 7 ) años y la mediana de PSA al diagnóstico fue de 5,4 (RIQ 4,3-6,8) ng/dl. En la patología definitiva, la mediana del volumen tumoral fue del $4 \%$ (RIQ: 1-10\%). El puntaje de Gleason fue de $3+3$ en 55 (66,3\%) pacientes, mientras que $28(33,7 \%)$ fueron reclasificados a uno mayor. Solo $2(2,4 \%)$ pacientes se reclasificaron como pT3a, $80(96,4 \%)$ pacientes fueron clasificados como pT2 y un $(1,2 \%)$ paciente fue reclasificado como pTO. No se evidenció compromiso ganglionar en ninguno de los pacientes llevados a linfadenectomía. Conclusión: Los hallazgos demuestran que hasta una tercera parte de los pacientes con tumores inicialmente clasificados como de muy bajo riesgo tienen puntajes de Gleason mayor en la patología definitiva; sin embargo, solo el $3 \%$ tienen tumores localmente avanzados, lo cual es consistente con lo reportado en la literatura mundial. Los criterios de Epstein son adecuados para predecir la presencia de tumores órgano-confinados.

Palabras clave

cáncer de próstata; prostatectomía; estatificación de neoplasias.

\section{Introduction}

With the advent of PSA as a tumor marker in the 1980s and the development of new biopsy schemes, diagnosis of prostate cancer (PCa), particularly in early stages of the disease, has substantially increased [[1]]. As most of these tumors will follow an indolent course, overdiagnosis and over-treatment have become a growing topic of interest [2]. The adverse effects and consequences related to treatment with curative-intent of potentially indolent PCa led to the introduction of Active Surveillance (AS) [3] as an alternative intended to defer curative treatment until biological activity of the tumor becomes evident [4,5]. Nonetheless, AS has raised several concerns, among them, the clinical understaging and undergrading, and the presence of unfavorable histological findings in certain patients that previously met very low risk criteria. For this reason, it is important to carefully analyze each of the management modalities.

Taking into account the above, our objective is to describe the histological findings in patients initially categorized with very low risk PCa who opted for treatment with radical prostatectomy (RP) in our institution.

\section{Material and Methods}

A retrospective observational study was conducted. Medical records from patients who underwent RP between January 2007 and December 2015 were reviewed. Patients who met Epstein's criteria for very low risk disease (clinical stage T1c, PSA density $<0.15 \mathrm{ng} /$ $\mathrm{ml}$, biopsy Gleason score $\leq 6$, presence of $\mathrm{PCa}$ in fewer than 3 biopsy cores and no more than $50 \%$ involvement in any of the cores) were included for analysis [6]. All biopsies were either performed or revised by our institution's Pathology Department. A data collection format was designed and applied to every medical records. Postoperative Gleason score, surgical margin status, seminal vesicle and lymph node involvement were reviewed. Patients with incomplete medical records were excluded.

The statistical analysis was conducted using the Stata 14 software with the advice of the institutional Department of Clinical Epidemiology. Absolute frequencies and percentages for qualitative variables were reported. Shapiro-Wilk normality test was applied to quantitative variables to determine normal or non-normal distribution and the 
central tendency and dispersion measures were reported.

\section{Results}

A total of $609 \mathrm{RP}$ procedures were reviewed from which $83(13.6 \%)$ very low risk PCa cases were identified and included. The Mean age at the time of the surgery was $59(\mathrm{SD} \pm 7)$ years old. Median PSA at diagnosis was 5.41 (IQR $4.3-6.8) \mathrm{ng} / \mathrm{dl}$. A total of $21(25.3 \%)$ patients reported a family history of $\mathrm{PCa}$ on the first degree.

The assessment of surgical specimens (Table 1) demonstrated a median tumor volume of $4 \%$ (IQR 1 - 10). A Gleason score of $3+3$ was confirmed in most of the cases $(66.3 \%)$, but up to one-third of the patients presented with unfavorable Gleason and thus they were reclassified. Definitive stage was pT2 in 80 (96.39\%) cases and only two (2.41\%) patients were reclassified as pT3a. One patient $(1.2 \%)$ presented with vanishing cancer phenomenon (pT0). Pelvic lymph node dissection was performed in 35 (42.17\%) patients, none of which had positive lymph nodes. There were no cases of seminal vesicle involvement.

For the analysis of the PSA values at 6, 12, and 18 months, the information was insufficient due to the missing data of more than $10 \%$ and it was not included as a result in our study.
Table 1.Histological Findings on the Radical Prostatectomy Specimen of Patients with very Low Risk Prostate Cancer

\begin{tabular}{|c|c|}
\hline Variable & $\mathrm{n}=8(\%)$ \\
\hline Positive surgical margins & $7(8.4)$ \\
\hline $\begin{array}{l}\text { Positive capsule } \\
\text { involvement }\end{array}$ & $3(3.6)$ \\
\hline Perineural invasion & $43(51.8)$ \\
\hline \multicolumn{2}{|c|}{ Gleason score } \\
\hline $3+3$ & $55(66.3)$ \\
\hline $3+4$ & $24(28.9)$ \\
\hline $4+3$ & $3(3.6)$ \\
\hline $4+4$ & $1(1.2)$ \\
\hline \multicolumn{2}{|c|}{ Tumor stage } \\
\hline pT0 & $1(1.2)$ \\
\hline $\mathrm{pT} 2 \mathrm{a}$ & $12(4.5)$ \\
\hline pT2b & $6(7.2)$ \\
\hline pT2c & $62(74.7)$ \\
\hline pT3a & $2(2.4)$ \\
\hline
\end{tabular}

\section{Discussion}

Prostate cancer is the most common malignant neoplasia in males in the United States since 1984. The risk of developing PCa is estimated at $16.72 \%$ and the risk of death is $2.57 \%$ [7]. Reports on autopsies have shown that about $50 \%$ of males aged 50 years and older have PCa [8]. However, this tumor's aggressiveness can be predicted to a certain extent through clinical parameters, mainly the Gleason score, PSA, and tumor stage (TNM). Stratification of patients in different risk groups with the purpose of defining their oncological prognosis relies on the combination of these parameters.

Low risk PCa has been established to include a Gleason score $\leq 6, \mathrm{PSA} \leq 10 \mathrm{ng} / \mathrm{ml}$ and clinical stage T1c-T2a [9]. The very low risk category was more recently created and incorporates the aforementioned parameters and other biopsy variables such as the number of positive cores, percentage of core involvement and PSA density. Certain studies have shown that very low risk disease is associated with a more favorable oncological prognosis and indolent course $[4,5]$. AS has been specifically proposed 
for these patients as a strategy to prevent overtreatment and reduce the morbidity related to $\mathrm{RP}$ and radiotherapy without compromising the possibility of cure $[3,10,11]$. The National Comprehensive Cancer Network (NCCN) as well as the American Urological Association (AUA) present AS as the first-line treatment option for patients with low and very low risk $\mathrm{PCa}$ $[12,13]$.

Our data indicates that around $13.6 \%$ of the patients undergoing RP met very low risk criteria, which is comparable to other series. Jeldres et al. [14] reported $14 \%$ of low risk tumors undergoing $\mathrm{RP}$ and Epstein et al. [15] reported a 10\%, which is probably related to the fact that for that time this was an accepted conduct.

Clinical undergrading and understaging are major concerns for recommending AS. The limitations of digital rectal examination and PSA as screening and diagnostic methods are well known. The Gleason score from the prostate biopsy has an undergrading rate close to $26 \%$ when compared to the pathological assessment of the RP specimen. Moreover, some patients may show lymph node involvement [16,17]. In the previously mentioned study of Jeldres et al. [14] the postoperative results of a total of 366 patients that met Epstein's criteria were analyzed and found that on the approximately a $20 \%$ had unfavorable findings. A Gleason score of 7 was evident in $88(24 \%)$ of the cases, $30(8.3 \%)$ of which had positive margins and 30 had locally advanced disease. There were no cases of lymph node involvement.

Another study published in 2004 by Bastian et al. [18] with a sample of 237 patients showed similar results regarding organ-confined disease $(91.6 \%)$, but with a lower rate of Gleason score 7 (9\%). Beauval et al. [19] with 919 cases that met strict criteria for AS found that the Gleason score was reclassified in 34\% of the cases and $1.2 \%$ had Gleason 8 or 9 . Definitive stage was pT2 in $87.3 \%$ of the patients, pT3 in $11.1 \%$ and pT4 in $1.4 \%$. Only $26 \%$ of the patients had nonsignificant tumors (stage $<\mathrm{pT} 3$, Gleason score $<$, and tumor volume $<0.5 \mathrm{ml}$ ).

Tolsoian et al. [20] in John's Hopkins compared the pathologic outcomes in patients who underwent delayed prostatectomy after active surveillance $(n=89)$ to those who chose immediate prostatectomy $(n=3788)$. In the immediate prostatectomy arm, 840 (22\%) patients were reclassified as Gleason 3+4, 416 $(11 \%)$ as Gleason $4+3$, and $122(3 \%)$ as Gleason $4+4$. Regarding tumor stage, $486(11.5 \%)$ were confirmed pT3a, and 120 (3.2\%) were pT3b. Positive margins and lymph nodes were evident in $439(11.6 \%)$ and $45(1.2 \%)$ cases respectively, which is comparable to our results.

After reviewing several series, it appears that Epstein's criteria for very low risk disease are useful in predicting organ confined disease in about $90 \%$ of the cases, but Gleason score reclassification happens in $25-35 \%$ of the cases after pathological assessment [21,22], and positive margins occurs in $7-12 \%$ of the cases. Although this would seem to worsen the prognosis, there is no evidence that these findings are necessarily associated with disease progression and the need for additional treatment, therefore we consider that meeting Epstein' criteria allows predicting a favorable outcome.

Magnetic resonance imaging is one of the strategies to improve prediction of postoperative results as it allows identifying non-palpable suspicious areas (and directing the biopsy) and detecting locally advanced disease [23]. Performing a second biopsy prior to the inclusion in an AS program has also been proposed $[23,24,25]$. More recently, different imaging methods and molecular tests have also been introduced [26, 27].

Our great strength is that in Colombia, to date, there are no published data concerning patients with very low risk $\mathrm{PCa}$ and the histological features of surgical specimens after RP. Therefore, our study provides a starting point for future research. A potential limitation of our study is the sample size, which although small, is representative of our population. Another limitation is that our series, similar to some of the series previously reviewed, lack information about oncological outcomes, which in turn prevents us from knowing the impact of such findings on the prognosis. 


\section{Conclusions}

Our findings show that up to one-third of patients with tumors initially classified as very low risk have higher Gleason scores in definitive pathology, and only 3\% have locally advanced tumors. This is consistent with what has been reported in the literature worldwide. Epstein's criteria are adequate in predicting the presence of organ-confined tumors. The lack of data on oncological follow-up prevents us from determining if having a higher Gleason score in a localized tumor scenario has an impact on the prognosis.

\section{References}

1. Schröder FH. Prostate cancer: To screen? BMJ. 1993;306:407-8.

2. Venderos Lionne DF, Roobol M, De Hoogh A. Active surveillance for prostate cáncer: A legal perspective. Am J Clin Exp Urol. 2014;2(4):323-31.

3. Klotz L, Vesprini D, Sethukavalan P, Jethava $\mathrm{V}$, Zhang L. et al. Long-term follow-up of a large active surveillance cohort of patients with prostate cancer. J Clin Oncol. 2015;33(3):272-7.

4. Schroder F, Roach M, Scardino P. Management of prostate cancer. $\mathrm{N}$ Engl J Med. 2008;359:2605-9.

5. Tosoian JJ, Carter HB, Lepor A, Loeb S. Active surveillance for prostate cancer: current evidence and contemporary state of practice. Nat Rev Urol. 2016;13(4):205-15.

6. Epstein JI, Walsh PC, Carmichael M, et al. Pathologic and clinical findings to predict tumor extent of nonpalpable (stage T1c) prostate cancer. JAMA. 1994;271:368-74.

7. Wein A, Kavoussi L, Partin A, Peters C. Campbell-Walsh urology. 10 th ed. Philadelphia: Elsevier; 2012.

8. Klotz L. Active surveillance for favorable-risk prostate cancer: Who, how and why? Nat Clin Pract Oncol. 2007;4:692-8.

9. D'Amico AV, Whittington R, Malkowicz SB, et al. Biochemical outcome after radical prostatectomy, external beam radiation therapy, or interstitial radiation therapy for clinically localized prostate cancer. JAMA. 1998;280(11):969-74.

10. Laurence. Active surveillance for prostate cancer: Trials and tribulations. World J Urol. 2008;26:437-42.

11. Parker C. Active surveillance: towards a new paradigm in the management of early prostate cancer. Lancet Oncol. 2004;5:101-6.

12. National Comprehensive Cancer Network. NCCN Clinical Practice Guidelines in Oncology: Prostate Cancer [internet]. Available from: http://www.nccn.org/profes sionals/physician_gls/PDF/prostate.pdf

13. American Urological Association. Guideline for the management of clinically localized prostate cancer [internet]. Available from: https://www.auanet.org/documents/e ducation/clinical-guidance/Prostate-Cance r.pdf

14. Jeldres C, Suardi N, Walz J, et al. Validation of the contemporary Epstein criteria for insignificant prostate cancer in European men. Eur Urol. 2008;54:1306-13.

15. Epstein JI, Chan DW, Sokoll LJ, et al. Nonpalpable stage T1c prostate cancer: prediction of insignificant disease using free/total prostate specific antigen levels and needle biopsy findings. J Urol. 1998;160:2407-11.

16. Kattan MW, Eastham JA, Wheeler TM, et al. Counseling men with prostate cancer: a nomogram for predicting the presence of small, moderately differentiated confined tumors. J Urol. 2003;170:1792-7.

17. Chun FK-H, Steuber T, Erbersdobler A, et al. Development and internal validation of a nomogram predicting the probability of prostate cancer Gleason sum upgrading between biopsy and radical prostatectomy pathology. Eur Urol. 2006;49:820-6.

18. Bastian PJ, Mangold LA, Epstein JI, Partin AW. Characteristics of insignificant clinical T1c prostate tumors: A contemporary analysis. Cancer. 2004;101:2001-5. 
19. Beauval JB, Ploussard G, Soulié M, Pfister C, Vanagt S, Vincendeau S, Larue S. Pathologic findings in radical prostatectomy specimens from patients eligible for active surveillance with highly selective criteria: a multicenter study. J. Urology. 2012;80:656-60.

20. Tosoian J, Sundi D, Trock BJ, Landis P, Epstein J, Schaeffer EM. Pathologic outcomes in favorable-risk prostate cancer: comparative analysis of men electing active surveillance and immediate surgery. Eur Urol. 2016;69:575-81.

21. Kulkarni JN, Valsangkar RS, Jadhav YR, Singh DP. Impact of Gleason pattern up gradation after radical prostatectomy for carcinoma prostate patients with low biopsy score $(\leq 6)$. J Cancer Res Ther. 2011;7:459-62.

22. Cookson MS, Fleshner NE, Soloway SM, Fair WR. Correlation between Gleason score of needle biopsy and radical prostatectomy specimen: accuracy and clinical implications. J Urol. 1997;157:559-62.

23. Chang JM, Lee HJ, Lee SE, et al. Pictorial review: unusual tumors involving the prostate: radiological-pathological findings. Br J Radiol. 2008;81:907-15.

24. Dall'Era MA, Konety BR, Cowan JE, et al. Active surveillance for the management of prostate cancer in a contemporary cohort. Cancer. 2008;112:2664-70.

25. Villers A, Lemaitre L, Haffner J, Puech P. Current status of MRI for the diagnosis, staging and prognosis of prostate cancer: Implications for local therapy and active surveillance. Curr Opin Urol. 2009;19:274-82.

26. Lindenberg L, AhLman M, Turkbey B, Mena E, Choyke P. Advancement of MR and PET/ MR in Prostate Cancer. Semin Nucl Med. 2016;46(6):536-43.

27. Bouchelouche K, Choyke PL. Prostatespecific membrane antigen positron emission tomography in prostate cancer: A step toward personalized medicine. Curr Opin Oncol. 2016;28:216-21. 